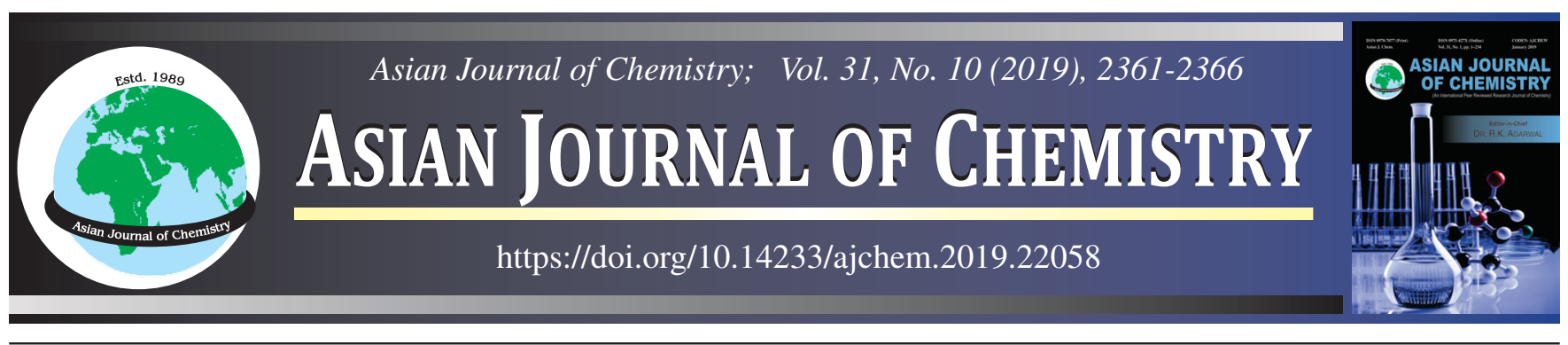

\title{
Growth Evaluation of Marine Microalgae Chlorella sp. BDU G91771 in Calcium Rich Ossein Effluent-A Bioremediation Perspective
}

\author{
B. Kalaiselvi ${ }^{*}$, G. Dayana Jeyaleela $^{\circledR}$, K. Prathiba, R. Ramyasri, S. Shiyamli and S. Vimala
}

P.G. \& Research Department of Chemistry, Holy Cross College (Autonomous), Tiruchirappalli-620002, India

*Corresponding author: E-mail: kalaihemaprakash@gmail.com

Received: 9 March 2019;

Accepted: 30 June 2019;

Published online: 30 August 2019;

AJC-19552

The aim of the present work is to study the growth and effluent parameters of the two ossein effluents. Growth parameters studied in this
article are protein, chlorophyll, carbohydrate, moisture and the effluent parameters are alkalinity, nitrates, nitrites, ammonia, phosphates,
sulphates, sulphites, calcium and magnesium. Calcium-rich effluent ossein was collected at three different clarifications stages from
pioneer Jellice Industries Pvt, Ltd, Cuddalore, which is gelatin manufacturing industry. The algae selected for the study was Chlorella
vulgaris BDU G91771 which was obtained from the culture collection of National Facility for Marine Cyanobacteria (NFMC), Bharathidasan
University, Tiruchirapalli, India. The culture was maintained in F/2 medium under the continuous white light at an intensity of $20 \mu \mathrm{mol}$
photon $\mathrm{m}^{-2} \mathrm{~s}^{-1}$ at $25 \pm 2{ }^{\circ} \mathrm{C}$ in a controlled culture room. The chosen organisms were grown in effluent diluted with seawater $(1: 1,2: 2$ and
3:1) amended with fertilizer grade nutrient enrichment and phosphorus sources. The untreated effluent parameters were analyzed. Chlorella
vulgaris was inoculated in F/2 medium and allowed to grow in ossein effluent for 7 days. The growth of the organism was measured by
calculating its culture density, dry weight, carbohydrate, protein and chlorophyll. The growth parameters of microalgae revealed that the
higher content of nitrate and ammonia in HTDS effluent served as the nitrogen source and supported microbial growth.

Keywords: Ossein effluent, Chlorella vulgaris, Growth parameters, Effluent parameters.

ᄂ - - - - - - - - - - - - - - - - - - - - - - - - - - - - - -

\section{INTRODUCTION}

Wastewaters from urban and industries must be treated before being excreted into the environment, in order to avoid unwanted effects such as pollution and hypertrophication [1]. Oswald and Gotaas [2] was first introduced the use of microalgae in the wastewater treatment process and has recognized much more interest in modern decades. Microalgae growth process such as eliminating impurities, preparing medium, purifying water and addition of nutrients are not necessary for the production process due to these main advantages the production cost is reduced [3]. Besides, during the process not only nutrients are removed from the waste but it also returned as an agricultural fertilizer to the terrestrial environment. Another benefit of utilization of microalgae in the wastewater treatment is photosynthetic $\mathrm{CO}_{2}$ fixation i.e. it contributes to reducing the liberation of greenhouse gas carbon dioxide and it produces flue gas that possesses a lot of industrial uses which are reported in Van den et al. [4].
Bioremediation is a process that controlling pollution by using microorganisms as a catalyst to consume and break down (degradation) the hazardous toxic polluted chemicals into less or non-toxic chemicals [5,6]. Usage of cyanobacteria effluent treatments is a current trend and its initial experiments were proposed and practiced as effluent in agricultural and industrial fields. In worldwide, it helps to solve excessive richness of nutrients (eutrophication) in water bodies. The richness of nutrients enhances the dense growth of aquatic plants and it results in the reduction of nutrient level (toxic chemicals) in the water bodies [7]. Biomass production of cyanobacteria in large quantity can be used as a food for animals and important sources for amino acids production, light photo conversion, toxins and secondary production, production of enzymes, vitamin and hydrogen, nitrogen fixation and drug intermediates in pharmaceuticals [8-11]. Cyanobacteria are environmentally friendly and do not show any toxic effect to other biotic components. Due to the size, the separation of cyanobacteria biomass is much easier compared to other microalgae biomass

This is an open access journal, and articles are distributed under the terms of the Attribution 4.0 International (CC BY 4.0) License. This license lets others distribute, remix, tweak, and build upon your work, even commercially, as long as they credit the author for the original creation. You must give appropriate credit, provide a link to the license, and indicate if changes were made. 
separations. The main organic component in the animal bone tissue is ossein (decalcified bone) which is obtained as a residue in the gelatin production during the clarification process. The major concerns in the disposal of the effluent ossein are a strong odour, high organic content, huge volume and high inorganic contents. Cattle bone decalcification produces a huge volume of calcium opulent effluent and they are dicalcium phosphate (DCP), low total dissolved solids (LTDS) and high total dissolved solids (HTDS). Dicalcium phosphate (DCP) is released during the acidification of the bones effluent formed after discharged, final washing followed by settlement of ossein is obtained and HTDS found at heat treatment of decalcified bones [2,12]. A marine microalgae Chlorella sp. BDU G91771 needs calcium, nitrogen, phosphorous as major nutrients for its growth. As the ossein effluent has major nutrients present work proposed to evaluate the growth of the organism in low total dissolved solids and high total dissolved solids ossein effluent to analyze the nutrient parameters in calcium rich ossein effluent.

\section{EXPERIMENTAL}

Selection of organism: Ossein effluents (HTDS and LTDS) obtained in the clarification process of gelatin production system was taken for the present study. The microalgae taken for the present work is Chlorella vulgaris. Unicellular, spherical green algae, cells are 5-10 micron in diameter, solitary or aggregated in irregular clumps, chloroplast cup or bowl-shaped. Its description and images are given in Table-1 and Fig. 1, respectively.

\begin{tabular}{lc|ll}
\multicolumn{4}{c}{ TABLE-1 } \\
& DESCRIPTION OF Chlorella vulgaris ALGAE \\
\hline Domain & Eukaryota & Order & Chlorellales \\
Kingdom & Viridiplantae & Family & Chlorellaceae \\
Division & Chlorophyta & Genus & Chlorella \\
Class & Trebouxiophyceae & Species & Vulgaris \\
\hline
\end{tabular}

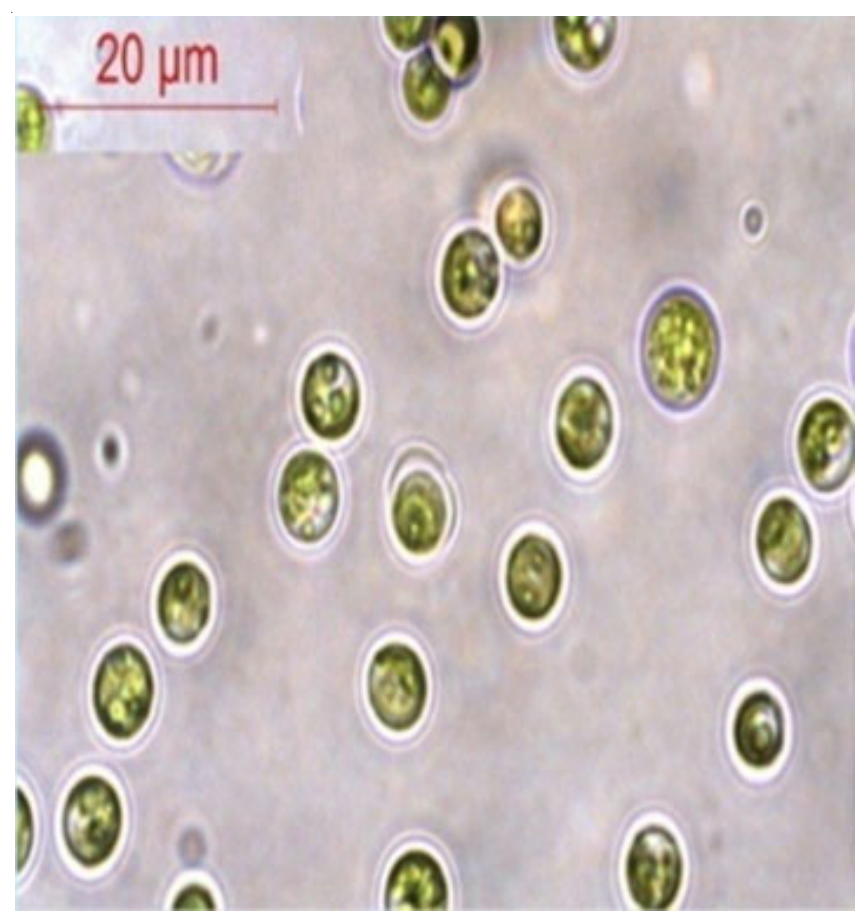

Fig. 1. Microscopic image of Chlorella vulgaris
Extraction and estimation of total protein: The main principle of the estimation of protein is the protein forms blue coloured complex with reagent Folin-Ciocalteu's phenol. This is due to the reduction of phosphomolybdate (in reagent) by tryptophan and tyrosine which is present in the protein aromatic amino acids present in the protein is responsible for the deep blue colour of the complex and it varies from protein to protein.

To $0.5 \mathrm{~g}$ of washed pellet, $5 \mathrm{~mL}$ of $10 \%$ trichloroacetic acid was added slowly and then left for $30 \mathrm{~min}$ in boiling water bath. The whole content was centrifuged at $500 \mathrm{rpm}$ for $10 \mathrm{~min}$ and discards the remaining liquids. The pellets were treated with $1 \mathrm{~mL}$ of $1 \mathrm{~N} \mathrm{NaOH}$ in boiling water bath for $30 \mathrm{~min}$. Aliquot of $0.1 \mathrm{~mL}$ was taken from that and made upto $1 \mathrm{~mL}$ with double distilled water. To this, $4 \mathrm{~mL}$ of alkaline reagent was added then stand for $30 \mathrm{~min}$ and $0.5 \mathrm{~mL}$ of FolinCiocalteu's phenol reagent was added further whole content was incubated for $30 \mathrm{~min}$ at room temperature. Finally, the absorbance of the solution was read at $750 \mathrm{~nm}$ and the amount of protein estimated by standard curve (bovine serum albumin) [13].

Chlorophyll: To study the growth and photosynthetic rates of algae chlorophyll estimation is an imperative biomass component. Chlorophyll-a absorbs $416 \mathrm{~nm}$ wavelength and chlorophyllb absorbs $453 \mathrm{~nm}$. A $0.5 \mathrm{~g}$ of cultured pellet was washed and suspended in vortex and $4 \mathrm{~mL}$ of methanol. To prevent solvent evaporation the mouth of the tubes are covered with aluminium foil. All the test tubes are incubated at $60{ }^{\circ} \mathrm{C}$ in a water bath for $1 \mathrm{~h}$ in dark with occasional shaking to arrest the oxidation process in light. After $1 \mathrm{~h}$, the whole content is centrifuged at $5000 \mathrm{rpm}$ for $10 \mathrm{~min}$ and the supernant are added to another tube containing $80 \%$ methanol [14]. The final sample was read at $663 \mathrm{~nm}$ and methanol used as a blank, the total chlorophyll was calculated by following equations:

Amount of chlorophyll 'a' $=6.4 \times\left(\mathrm{A}_{416}-0.79\right) \times \mathrm{A}_{453}$

Amount of chlorophyll 'b' $=5.87 \times\left(\mathrm{A}_{453}-0.24\right) \times \mathrm{A}_{416}$

Carbohydrate: The method can be used for estimation of total sugars in samples. The sugars in the presence of conc. $\mathrm{H}_{2} \mathrm{SO}_{4}$ get dehydrated and produce furfural (from hexoses) or 5-hydroxymethylfurfural (from pentoses), which when reacted with anthrone produces a coloured compound with $\lambda_{\max }$ of 625 $\mathrm{nm}$. Pentoses, hexoses, heptoses and their derivatives yield a coloured product whereas trioses, tetroses and amino acids do not yield any coloured product.

To a $1 \mathrm{~mL}$ of cyanobacterial suspension added $4 \mathrm{~mL}$ of anthrone reagent. It was kept in a boiling water bath for $15 \mathrm{~min}$. The tubes were cooled preferably in ice and the absorbance was read at $620 \mathrm{~nm}$. The amount of carbohydrate was estimated from the standard curve prepared using a standard glucose solution [15].

Total moisture content: The culture was centrifuged at $5000 \mathrm{rpm}$ for $10 \mathrm{~min}$ and the pellet was washed twice with distilled water. Pellet was taken in preweighed aluminium foil and it was dried at $50{ }^{\circ} \mathrm{C}$ in a hot air oven until two or three concurrent weights remain the same [16-19].

\section{Effluent parameters estimation}

Alkalinity: In commonly natural water contains carbonates and bicarbonates in form of their salts which get hydrolyzed 
in water and produces hydroxyl ions thus, raising the $\mathrm{pH}$ to make the water into more alkaline nature. Usually, alkalinity determined by titration the sample against strong acid (standard solution). The total amount of hydroxide and carbonate is determined by the first end-point ( $\mathrm{pH}$ 8.3) using phenolphthalein indicator and the total amount of bicarbonate is determined by the second end-point ( $\mathrm{pH} 4.5$ ) using methyl orange indicator.

A $50 \mathrm{~mL}$ of sample solution was pipetted out in the conical flask and two-drops of phenolphthalein indicator added then, titrate against sulphuric acid and end-point is colourless. Endpoint reading is noted as ' $\mathrm{p}$ ' then, added two drops of methyl orange to that same conical flask and continue to titrate till the colour changes from yellow to orange. Second end-point reading is noted as ' $\mathrm{t}$ ' and total alkalinity was calculated using the following equation, where the total alkalinity is expressed as $\mathrm{mg} \mathrm{L}^{-1}$ of $\mathrm{CaCO}_{3}$.

Phenolphthalein alkalinity $=\frac{\mathrm{mL} \text { of titrant ' } \mathrm{P} ' \times 1000 \mathrm{mg} \mathrm{CaCO}_{3}}{\mathrm{~mL} \text { of the sample }}$

Total alkalinity $(\mathrm{T})$ as $\mathrm{mg} / \mathrm{L} \mathrm{CaO}_{3}=\frac{\mathrm{mL} \text { of titrant ' } \mathrm{t} \text { ' } \times 1000}{\mathrm{~mL} \text { of sample }}$

Chloride: Estimation of chloride ions in the sample solution is determined by titrating sample solution against silver nitrate solution using potassium chromate as an indicator. At the end point, the chloride concentration in the solution reaches to zero and silver ion converted into silver chromate which is in the reddish-brown product. Pipetted out $50 \mathrm{~mL}$ of water sample (if sea water is taken pipette $0.5 \mathrm{~mL}$ of sample) into a conical flask and added $0.5 \mathrm{~mL}$ of $\mathrm{K}_{2} \mathrm{CrO}_{4}$ indicator it gives yellow colour to the sample. Titrate the test solution by shaking it against standard silver nitrate solution till the development of reddish brown colour precipitate and repeated for concordant value. The blank titration was done by using $50 \mathrm{~mL}$ of deionized chloride free water sample and $0.5 \mathrm{~mL}$ of indicator. The total amount of chlorides present in the sample was expressed in $\mathrm{mg} \mathrm{L}^{-1}$.

$$
\text { Chloride }(\mathrm{mg} / \mathrm{L})=\frac{\mathrm{mL} \text { of titrant used } \times \mathrm{N} \times 35.46 \times 1000}{\mathrm{~mL} \text { of sample }}
$$

where $\mathrm{N}=$ normality of titrant

Salinity: The salinity of water sample is detected from the chlorinity of water sample.

\section{Chlorinity of sample $=$}

Chlorinity of Std. sea water sample $\times$

$19.369 \times$ Vol. of the titrant used for chloride

Volume of $\mathrm{AgNO}_{3}$ used for standard water (19.3)

Salinity ppt $(\%)=0.03+(1.805 \times$ Chlorinity $)$

Nitrate: Nitrates in the sample solution were estimated by using 1,2,4-phenoldisulphonic acid and it forms 6-nitro, 2,4-acid (an alkaline salt) complex with the nitrates which gives yellow colour with the test solution. The alkaline salt absorbs $410 \mathrm{~nm}$ wavelength. For the estimation of nitrates, a series of $50 \mathrm{~mL}$ different concentration of nitrate solutions are prepared from standard solution (10 to $100 \mu \mathrm{g}$ ).

Pipette out $2 \mathrm{~mL}$ of each standard solution into different dry $100 \mathrm{~mL}$ beakers with the glass-rods. Added $1 \mathrm{~mL}$ of a brucine- sulphanilic acid reagent to each baker and followed by $10 \mathrm{~mL}$ of sulphuric acid solution is added. Then the solution was stirred gently for about $5 \mathrm{~min}$ and all the beakers were covered with the help of aluminium foil sheets along with the watch glasses. Kept all the beakers in the dark for $10 \mathrm{~min}$ at room temperature and yellow colours appeared in the beaker solutions. Again added $10 \mathrm{~mL}$ of double distilled water to each beaker and incubated in the dark for $30 \mathrm{~min}$ at room temperature and finally, the absorbance of each solution was measured at 410 $\mathrm{nm}$. A graph was plotted between the absorbance values against the concentration of the standard nitrate solutions. Total nitrate content was determined by using the standard graph and expressed in $\mathrm{mg} \mathrm{L}^{-1}$ [20-22].

Nitrite: Nitrite forms nitrous acid in acid medium and it is due to the diazotization of sulphanilamide. The diazonium salt when reacted with an aromatic amine, N-1-naphthylethylene diamine dihydrochloride, forms a red azo dye which is determined spectrophotometrically at $543 \mathrm{~nm}$.

A $20 \mathrm{~mL}$ of the sample was taken in a $50 \mathrm{~mL}$ volumetric flask and added $1 \mathrm{~mL}$ of sulphanilamide reagent then mixed well. After 5 min interval, $1 \mathrm{~mL}$ Griess reagent is added and the whole content is made upto $50 \mathrm{~mL}$ by using double distilled water. Before measuring the absorbance of solution, the whole content is shaked well and read at $543 \mathrm{~nm}$ using distilled water as a blank. The amount of nitrite content was calculated from the standard graph and the amount of $\mathrm{NO}_{2}$ nitrogen was expressed in $m g \mathrm{~L}^{-1}$.

Ammonia: Ammonia present in the sample solution can react with phenol and alkaline hypochlorite and forms indophenol blue. Nitroprusside or ferrocyanide used as a reaction catalyst. The absorbance of the reaction complex can be read by spectrophotometer at $640 \mathrm{~nm}$.

To a test sample, $0.4 \mathrm{~mL}$ of phenol reagent and $0.4 \mathrm{~mL}$ of nitroprusside reagent were added and mixed well. To this solution, $1 \mathrm{~mL}$ of oxidizing reagent was added and closes the tubes immediately then vortex and incubated for $1 \mathrm{~h}$ at room temperature in the dark room. Finally, measure the absorbance of solution at $640 \mathrm{~nm}$ in a spectrophotometer. The total amount of ammonia nitrogen was determined and expressed in $\mathrm{mg} \mathrm{L}^{-1}$.

Total phosphate: In the estimation of phosphate, total phosphorus was determined in the form of orthophosphates. The organically bound phosphorus is converted into inorganic phosphorus on oxidation with potassium persulphate because of the reduction of sulphuric acid. Phosphorous in the presence of ascorbic acid (reducing agent) is reduced to molybdenum blue with ammonium phosphomolybdate reagent.

A $50 \mathrm{~mL}$ of test solution was taken in a beaker and heated till the volume was reduced to $15 \mathrm{~mL}$ and added $1 \mathrm{~mL}$ of perchloric acid and then heated until the volume becomes $5 \mathrm{~mL}$. To this, $2 \mathrm{~mL}$ of phenolphthalein indicator was mixed and added $\mathrm{NaOH}$ solution dropwise until the solution turns into pink then it is made upto $50 \mathrm{~mL}$ using distilled water. Finally, $2 \mathrm{~mL}$ of mixed reagent was added followed by $2 \mathrm{~mL}$ of potassium persulphate was mixed then incubated for $10 \mathrm{~min}$. The absorbance of test solution was measured at $882 \mathrm{~nm}$ and the total phosphorus content in effluent was determined by the standard curve.

Sulphate: Total sulphate was estimated by the formation of $\mathrm{BaSO}_{4}$ complex with barium in acid solution and it forms 
uniform size crystal when the glycerol-ethanol solution is used as a stabilizer. The quantitative estimation of $\mathrm{BaSO}_{4}$ can easily be determined by spectrophotometer at a wavelength of 420 nm.

A $50 \mathrm{~mL}$ of test sample was taken then $10 \mathrm{~mL}$ of $\mathrm{NaCl}-$ $\mathrm{HCl}$ solution and $10 \mathrm{~mL}$ of glycerol-ethanol solutions were added one by one and kept this in the stirrer. At the same time, $0.15 \mathrm{~g}$ of barium chloride was added and kept this stirrer for $60 \mathrm{~s}$ at room temperature. The absorbance of the test solution was immediately read at $420 \mathrm{~nm}$ and the total amount of sulphate was measured.

Sulphide: The total amount of sulphide in the sample was determined by allowing sulphide to react with phenanthroline in the presence of an acidic medium and it gives an orange colour at the reaction time. This colouration is due to the reduction of phenanthroline.

To a $10 \mathrm{~mL}$ of test solution, $7 \mathrm{~mL}$ of acetate buffer $(\mathrm{pH}$ 3.5 ) and $3 \mathrm{~mL}$ of $0.1 \%$ phenanthroline monohydrate were added and made up to $25 \mathrm{~mL}$ with double distilled water and incubated for $1 \mathrm{~h}$ at $25^{\circ} \mathrm{C}$. The sample and standard solution absorbance were measured at $510 \mathrm{~nm}$. From the standard curve, the amount of sulphide was calculated and expressed in $\mathrm{mg} \mathrm{L}^{-1}$

Calcium and magnesium: Calcium and magnesium ions forms a complex with Eriochrome black T which forms winered colour complexes with metal ions. Metal ions form the dye complex with disodium salt of EDTA giving the blue colour to dye complex and similarly, murexide indicator forms the pink coloured complex with metal ions. With the addition of disodium salt of EDTA, the $\mathrm{Ca}^{2+}$ forms a colourless chelate complex leaving behind a purple solution of the dye.

A $5 \mathrm{~mL}$ of test sample taken into a $250 \mathrm{~mL}$ conical flask and added $5 \mathrm{~mL}$ of ammonium buffer to this then diluted to $100 \mathrm{~mL}$ with double distilled water. A pinch of Eriochrome black $\mathrm{T}$ was added to this solution and warmed at $60^{\circ} \mathrm{C}$ then titrated against EDTA until the red turns into blue colour. The final end-point was noted as 'A'.

To another conical flask, pipette out $5 \mathrm{~mL}$ of water sample to this $5 \mathrm{~mL}$ of $\mathrm{NaOH}$ solution was added and made up to 100 $\mathrm{mL}$ using deionized water [23-26], then added a pinch of murexide indicator. The final solution was titrated against EDTA and the end point colour changes from pink to blue. The end-point was noted as ' $\mathrm{B}$ ' and the total amount of $\mathrm{Ca}^{2+}$ and $\mathrm{Mg}^{2+}$ ions in the sample were calculated by the following standard equations:

Amount of calcium in the sample $(\mathrm{mg} / \mathrm{L})=\frac{\mathrm{F} \times \mathrm{B} \times 1000}{\text { Volume of sample }}$

Amount of magnesium in sample $(\mathrm{mg} / \mathrm{L})=\frac{\mathrm{F} \times \mathrm{A}-\mathrm{B} \times 1000}{\text { Volume of sample }}$

where, $\mathrm{A}=$ volume of EDTA consumed by $\mathrm{Ca}$ and $\mathrm{Mg}(\mathrm{mL})$; $\mathrm{B}=$ volume of EDTA consumed by $\mathrm{Ca}$ alone $(\mathrm{mL}) ; \mathrm{A}-\mathrm{B}=$ volume of EDTA consumed by $\mathrm{Mg}$ alone $(\mathrm{mL})$. Factor value for calcium $(\mathrm{F})$ is 2 and Factor value for magnesium $(\mathrm{F})$ is 1.2

\section{RESULTS AND DISCUSSION}

Estimation of protein, chlorophyll, carbohydrate and moisture content: From Table-2, total amount of protein, chlorophyll, carbohydrate and moisture content results were listed. The marine microalgae, Chlorella $\mathrm{sp}$. was grown in two effluents namely high total dissolved solids (HTDS) and low total dissolved solids (LTDS). The undiluted ossein effluent didn't support the growth of the organism. In order to facilitate growth further, the effluents were amended with nitrogen (urea) and phosphorous (rock phosphate) sources. The organism was able to establish growth in the effluents HTDS and LTDS. When grown in LTDS 1:1 effluent, Chlorella sp. yields a maximum of $486.46 \mu \mathrm{g}$ chlorophyll a and $483.261 \mu \mathrm{g}$ chlorophyll b, which was very low than the initial inoculum. However in HTDS effluent, the organism produced a maximum of $5825.37 \mu \mathrm{g}$ and $5733.293 \mu \mathrm{g}$ chlorophyll a and b, respectively. This was nearly double the amount of chlorophyll produced in the growth medium. From Fig. 2, it could be inferred that the organism is capable of growing in HTDS ossein effluent. This could be a good sign as growing microalgae could remediate the ossein effluent.

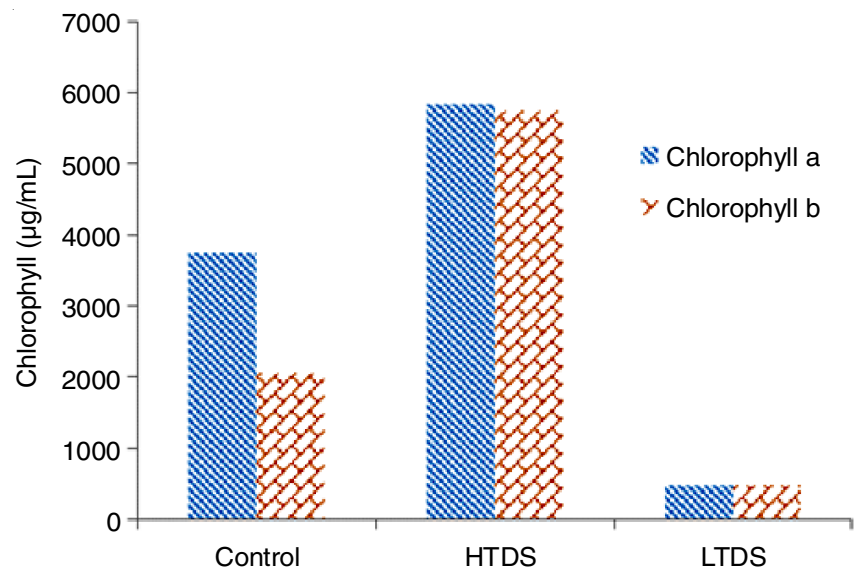

Fig. 2. Growth of Chlorella sp. in terms of chlorophyll a and chlorophyll $b$ in ossein effluent HTDS and LTDS

The culture density is shown in Fig. 3, which also revealed the same result that HTDS effluent supporting more growth than LTDS. From Fig. 4, it was found that carbohydrate content of organism at the end of five days growth was higher in HTDS effluent with $80 \mathrm{mg} / \mathrm{L}$ as compared to $65 \mathrm{mg} / \mathrm{L}$ and $40 \mathrm{mg} / \mathrm{L}$ in LTDS and in control growth medium, respectively. In contrast, the protein content was lower in both HTDS and LTDS grown effluent compared to the control cultures (Table-2).

Effluent parameter estimation in HTDS and LTDS ossein effluent: The characteristics of two ossein effluents (LTDS and

TABLE-2

DETERMINATION OF PROTEIN, TOTAL CARBOHYDRATE, TOTAL MOISTURE CONTENT, CHLOROPHYLL ' $a$ ' AND CHLOROPHYLL ' $b$ '

\begin{tabular}{cccccccc}
\hline Medium & $\begin{array}{c}\text { Protein } \\
(\mu \mathrm{g} / \mathrm{mL})\end{array}$ & $\begin{array}{c}\text { Carbohydrate } \\
(\mu \mathrm{g} / \mathrm{mL})\end{array}$ & Dry weight $(\mathrm{g})$ & $\mathrm{A}_{416 \mathrm{~nm}}$ & $\mathrm{~A}_{453 \mathrm{~nm}}$ & $\begin{array}{c}\text { Chlorophyll 'a' } \\
(\mu \mathrm{g} / \mathrm{mL})\end{array}$ & $\begin{array}{c}\text { Chlorophyll ‘b’ } \\
(\mu \mathrm{g} / \mathrm{mL})\end{array}$ \\
\hline Culture & 0.610 & 40 & 0.101 & 1.5121 & 0.7950 & 3741.308 & 2062.864 \\
HTDS & 0.392 & 80 & 0.093 & 2.4904 & 2.2496 & 5825.376 & 5733.293 \\
LTDS & 0.198 & 65 & 0.106 & 0.2014 & 0.1893 & 486.46 & 483.261 \\
\hline
\end{tabular}



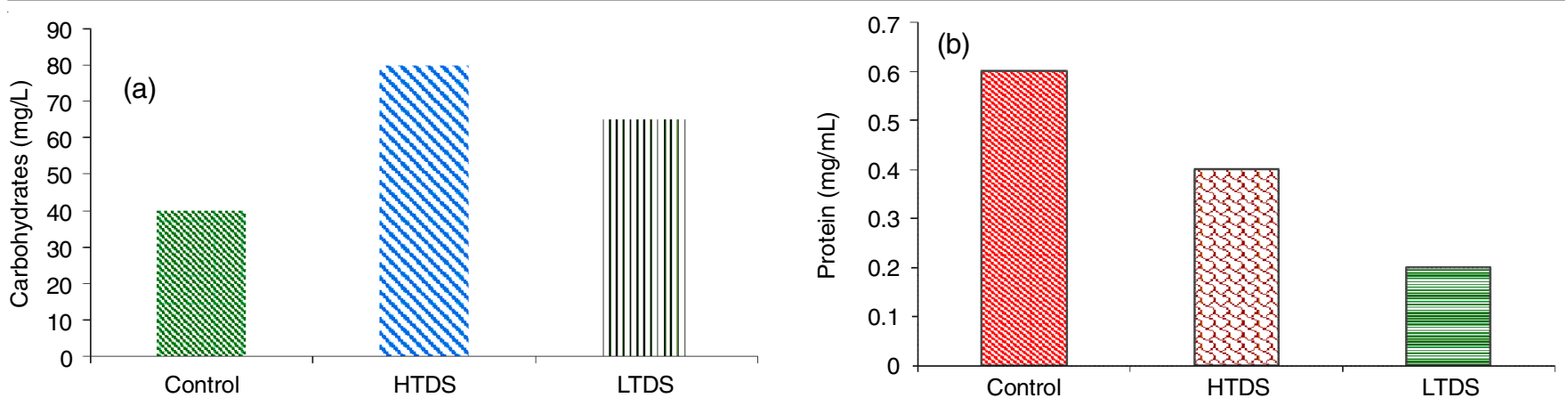

Fig. 4. Carbohydrate (a) and protein content (b) of Chlorella sp. BDUG91771 in different ossein effluent

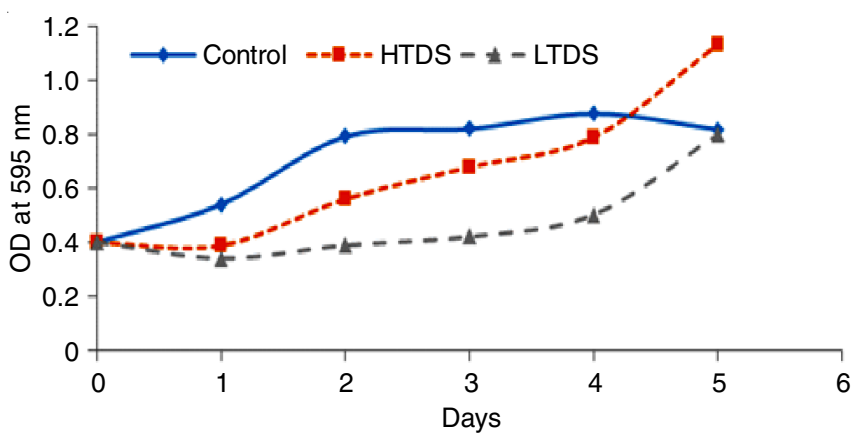

Fig. 3. Growth of Chlorella sp. BDU G91771 in terms of culture density measured at $595 \mathrm{~nm}$

HTDS) were highly variable because they were collected at different stages of treatment. In general, HTDS was characterized by yellowish colour, high calcium, magnesium and dissolved solids. The nutrients in HTDS and LTDS ossein effluents are given in Table-3. The HTDS effluent contained higher nitrate while the nitrite was higher in LTDS effluent. The high nitrate and ammonia in HTDS effluent might serve as the nitrogen source and support microalgal growth. No heavy metals were found in the effluent.

\begin{tabular}{lcc}
\multicolumn{3}{c}{ TABLE-3 } \\
\multicolumn{3}{c}{$\begin{array}{c}\text { EFFLUENT PARAMETERS IN HTDS } \\
\text { AND LTDS OSSEIN EFFLUENT }\end{array}$} \\
\hline \multicolumn{1}{c}{ Parameters } & LTDS $\left(\mathrm{mg} \mathrm{L}^{-1}\right)$ & HTDS $\left(\mathrm{mg} \mathrm{L}^{-1}\right)$ \\
\hline Alkalinity & 3.8 & 19.7 \\
Nitrate & 0.1779 & 2.037 \\
Nitrite & 1.6075 & 0.0671 \\
Ammonia & 0.2193 & 2.253 \\
Total phosphate & 0.9172 & 1.872 \\
Sulphate & 0.5077 & 0.0756 \\
Sulphite & 0.4567 & 0.0935 \\
Calcium & 120 & 6400 \\
Magnesium & 40 & 840 \\
\hline
\end{tabular}

From chlorophyll a, chlorophyll b and culture intensity of the organism measured during the culture period in different effluents, it was observed that among the two different ossein effluents tested, HTDS effluent supported better growth than the LTDS effluent. This may be due to the presence of higher nitrate (2.037 $\left.\mathrm{mg} \mathrm{L}^{-1}\right)$ and ammonia (2.253 $\left.\mathrm{mg} \mathrm{L}^{-1}\right)$ in the HTDS effluent compared to its level in LTDS effluent. Uma et al. [22] have utilized two marine cyanobacterium, Oscillatoria willei BDU 130791 and Phormidium valderianum BDU20041 in treating seawater diluted ossein effluent. In this study, the effluents were not diluted with sea water and used as such.
The growth exhibited in the HTDS effluent is very promising that the organism could be used to treat the effluent in further experiments. The abundance of calcium in the effluent is another unique way of remediating the effluent, the excess calcium along with bicarbonate can be sequestered as calcium carbonate and it could be precipitated and removed, later thus making the wastewater more usable for irrigation.

\section{Conclusion}

In the present study, Chlorella sp. is used to analyze the growth and nutrient parameters in calcium-rich ossein effluent. The present study not only aims at bioremediation of ossein effluent by Chlorella sp. but also gives the idea about the microbial growth in the same. It is concluded that the higher content of nitrate and ammonia in HTDS effluent serve as the nitrogen source and support microbial growth. These microalgae wastewater treatment is eco-friendly and offers the advantage of a cost-effective way of nutrient removal and biomass production.

\section{CONFLICT OF INTEREST}

The authors declare that there is no conflict of interests regarding the publication of this article.

\section{REFERENCES}

1. P. Chellapandi, D. Prabaharan and L. Uma, Appl. Biochem. Biotechnol., 162, 524 (2010);

https://doi.org/10.1007/s12010-009-8834-2.

2. W.J. Oswald and H.B. Gotaas, Trans. Am. Soc. Civ. Eng., 122, 73 (1957).

3. D. Francisca Kalavathi, L. Uma and G. Subramanian, Enzyme Microb. Technol., 29, 246 (2001);

https://doi.org/10.1016/S0141-0229(01)00383-0.

4. S. Van den Ende, H. Vervaeren and N. Boon, Biotechnol. Adv., 30, 1405 (2012);

https://doi.org/10.1016/j.biotechadv.2012.02.015.

5. I. Godos, V.A. Vargas, S. Blanco, M.C.G. González, R. Soto, P.A. GarcíaEncina, E. Becares and R. Muñoz, Bioresour. Technol., 101, 5150 (2010); https://doi.org/10.1016/j.biortech.2010.02.010.

6. J.-P. Hernandez, L.E. de-Bashan and Y. Bashan, Enzyme Microb. Technol., 38, 190 (2006);

https://doi.org/10.1016/j.enzmictec.2005.06.005.

7. C. Hills and H. Nakamura, Food from Sunlight, World Hunger Research Publ.: Boulder Creek, CA, USA (1978).

8. J. Ho and S. Sung, Bioresour. Technol., 101, 2191 (2010); https://doi.org/10.1016/j.biortech.2009.11.042.

9. D.F. Kalavathi, L. Uma and G. Subramanian, Indian J. Microbiol., 41, 319 (2001).

10. N. Mallick, Biometals, 15, 377 (2002); https://doi.org/10.1023/A:1020238520948.

11. W. Mulbry, S. Kondrad and P. Pizarro, J. Veg. Sci., 12, 107 (2007); https://doi.org/10.1300/J484v12n04_08. 
12. W. Mulbry, S. Kondrad, C. Pizarro and E. Kebede-Westhead, Bioresour. Technol., 99, 8137 (2008); https://doi.org/10.1016/j.biortech.2008.03.073.

13. O.H. Lowry, N.J. Rosebrough, A.L. Farr and R.J. Randall, J. Biol. Chem., 193, 265 (1951).

14. Q. Mackinney, J. Biol. Chem., 140, 315 (1941).

15. J.E. Hedge and B.T. Hofreiter, eds.: R.L. Whistler and J.N. Be Miller, In: Carbohydrate Chemistry, Academic Press: New York (1962).

16. S. Palanisami, K. Kannan and U. Lakshmanan, J. Appl. Phycol., 24, 1093 (2012); https://doi.org/10.1007/s10811-011-9738-4.

17. I. Priyadarshani and B. Rath, J. Algal Biomass Util., 3, 89 (2012).

18. C. Pualchamy, P. Dharmaraj and U. Laxmanan, EurAsian J. Biosci., 2, 110 (2008)

19. I. Rawat, R. Ranjith Kumar, T. Mutanda and F. Bux, 2010. Dual role of microalgae: Phycoremediation of domestic wastewater and biomass production for sustainable biofuels production. App Energy. https://doi.org/10.1016/j.apenergy.2010.11.025.

20. S.K. Saha, P. Swaminathan, C. Raghavan, L. Uma and G. Subramanian, Bioresour. Technol., 101, 3076 (2010); https://doi.org/10.1016/j.biortech.2009.12.075.
21. L. Travieso, F. Benítez, E. Sánchez, R. Borja, M. León, F. Raposo and B. Rincón, Environ. Technol., 29, 985 (2008); https://doi.org/10.1080/09593330802166228.

22. V.S. Uma, G. Dineshbabu, G. Subramanian, L. Uma and D. Prabaharan, Bioremediat. Biodegrad., 5, 1000257 (2014); https://doi.org/10.4172/2155-6199.1000257.

23. C. Vílchez, I. Garbayo, M.V. Lobato and J.M. Vega, Enzyme Microb. Technol., 20, 562 (1997); https://doi.org/10.1016/S0141-0229(96)00208-6.

24. B. Wang, Y. Li, N. Wu and C.Q. Lan, Appl. Microbiol. Biotechnol., 79, 707 (2008); https://doi.org/10.1007/s00253-008-1518-y.

25. I. Woertz, A. Feffer, T. Lundquist and Y. Nelson, J. Environ. Eng., 135, 1115 (2009); https://doi.org/10.1061/(ASCE)EE.1943-7870.0000129.

26. X. Yuan, A. Kumar, A.K. Sahu and S.J. Ergas, Bioresour. Technol., 102, 3234 (2011) https://doi.org/10.1016/j.biortech.2010.11.019. 